\title{
Abortion - a philosophical perspective
}

\author{
MN Jali, M.S; M.Phil, Department of Nursing Science, University of the North
}

\section{Abstract}

The central issue in the abortion debate is the moral status of the conceptus. There are two positions that argue this issue. At one extreme are the views of the pro-life group which argues that human life begins at the moment of conception whilst at the other are views of the pro-choice group that argues in favour of a woman's right to self-determination. Two basic principles come into conflict in this debate, namely the Value of Life and that of Self-determination. In this paper the arguments forwarded by each group in justification of its position are presented. Also discussed is the moderate developmental viewpoint which accepts that the genetic basis of an individual is established at conception. Some development, however, has to occur before the conceptus can be called a person. The fact that an entity is a potential person is a prima facie reason for not destroying it. On the other hand, we need not conclude that a person has a right to life by virtue of that potentiality. Simultaneously we should recognise that the right a potential entity has, may be nullified by the woman's right to self-determination.

\section{Opsomming}

Die kernsaak in die aborsiedebat is die morele status van die gekonsepteerde. Daar is twee standpunte wat hierdie onderwerp beredeneer. Aan die een uiterste is die standpunte van die pro-lewe groepe wat redeneer dat menslike lewe ' $n$ aanvang neem met die oomblik van bevrugting (konsepsie) terwyl die pro-keuse groep ten gunste van 'n vrou se reg tot selfbeskikking argumenteer. Twee basiese beginsels kom in konflik in hierdie debat, naamlik die Waarde van Lewe en dié van Selfbeskikking. In hierdie artikel word die standpunte van elkeen van die groepe weergegee. Die gematigde ontwikkeling-standpunt wat aanvaar dat die genetiese basis van ' $n$ individu bepaal word by konsepsie word ook weergegee. 'n Mate van ontwikkeling moet egter plaasvind voordat die gekonsepteerde as 'n persoon beskou kan word. Aan die ander kant, hoef ons egter nie tot die gevolgtrekking te kom dat 'n persoon 'n reg op lewe het as gevolg van daardie potensiaal nie. Ons moet terselfdertyd erken dat die reg wat 'n potensiële entiteit het, uitgewis kan word deur die vrou se reg tot selfbeskikking.

\section{Introduction}

Abortion has become one of the most debated and emotional issues facing South Africa. The language that is used in the debate and the seemingly irreconcilable values are deeply felt to the extent that it can well test the foundation of our new democracy.

There are two types of abortion namely, spontaneous and induced abortion. The discussion in this paper will focus on induced abortion.

The main focus of this paper is to determine the morality or immorality of abortion. This will be done by concentrating on the fundamental philosophical questions that lie at the core of the abortion issue: Is a foetus a person? If so when does it become a person? Also of importance is the differentiation between potential and actual human life. There are two groups that attempt to answer these questions. The pro-life group argues against abortion while the pro-choice group argues for abortion. According to the pro-life group human life begins from the moment of conception and abortion is murder of defenceless human beings. The pro-choice group, on the other hand, argues in favour of the woman's right to self-determination. Abortion can therefore not be murder. The moderate viewpoint which accepts that human life in potentiality exist in various stages of development throughout pregnancy will also be discussed.

\section{Abortion}

Abortion is the expulsion of the products of conception from the uterus. It can either be spontaneous or induced. According to Davis and Aroskar (1983:114) spontaneous abortion occurs as a result of a variety of endogenous and exogenous causes, excluding intentional human interference, whereas induced abortion occurs as a result of intentional interference to deliberately terminate pregnancy.

\section{Biological Background}

All humans develop from a zygote which is formed when a human sperm fertilises a human ovum. The zygote undergoes a process of cellular multiplication as it slowly moves through the fallopian tube to be implanted in the uterine wall. The zygote is called a conceptus during the process of fertilisation. This process takes place between seven (7) to nine (9) days.

The embryonic stage begins on the third week after fertilisation and continues until the eighth week of pregnancy. By the end of the eighth week, the embryo is called a foetus because it has sufficiently developed and begins to look human. At this stage, brain waves can be monitored. Quickening which occurs by about the eighteenth week is another milestone in the developing pregnancy. 
By the end of the twenty fourth week, the foetus is said to be viable because its organ systems have developed to such an extent that it is capable of surviving on its own outside the uterus.

The biological data, however, do not make it easy to determine when life really begins. They do not help answering questions such as: What is a person? Does a foetus have a right not to be born because of severe abnormalities? There are no easy answers to these fundamental philosophical questions (Grassian 1992:244-245).

\section{Historical and Religious Background}

Grassian (1992:246) states that in ancient Greece and in Rome people resorted to abortion without any scruple. Deformed babies or unwanted female babies were often left to die. Aristotle believed that the characteristic that made a physical body human was the human soul. However, he did not conceive the soul as a substance that is found in the body. Instead, he saw the soul as the function of the body. He believed that a body had a human soul when it was capable of performing the functions that were unique to human beings and this was possible only when the body assumed a human shape and human organs (Grassian 1992:246).

The Aristotelean view of the soul was later rejected and the Cartesian dualism of Descartes (1596-1650) gained influence. According to the Cartesian view, the "soul and body are two different sort of substances, capable of existing independently" (Grassian 1992:246). Descartes saw a human being as a combination of these two radically different and interacting substances. From this perspective, the soul was seen as an immortal, conscious substance that occupied a body for a period of time. Philosopher, religious leaders and medical practitioners however, continued to debate the morality of abortion. The result of these debates was the development of the Hippocratic Oath which took a stand against abortion. However, the Oath was often violated. This practice continued until the emergence of Christianity, during which period the Hippocratic Oath was regarded as the only truth in medical ethics (Davis and Aroskar 1983:117-118; Grassian 1992:246). In the Seventeenth century, the church accepted the view that a human foetus has a body from the moment of conception. According to this view, foetal development consists of a continuous increase in size of organs and bodily structures which were believed to be present from the moment of conception. The position of the Roman Catholic Church on abortion has been very clear since the late 1880 s. Its position today and that of other religious leaders is that an embryo becomes a person the moment it is infused with an immortal soul. When this ensoulment takes place is an open question. Some of the early teachers of the church like St Thomas Aquinas believed that ensoulment occurred at about three months after conception. In 1869 Pope Pius IX ruled that all foetuses should be considered to be ensouled from conception. Many of the Protestant churches do not agree with the Roman Catholic Church on ensoulment. They do, however, regard abortion as undesirable, though not a mortal sin. To them, life is sacred and as such abortion is undesirable. In answering the question: When does human life begin? Most Protestant leaders agree that human life begins during quickening (Davis and Aroskar 1983:118; Grassian 1992:246-247).

\section{The Legal Background}

Before the inception of democracy in South Africa, the legal position as encapsulated in Abortion and Sterilisation Act No 2 of 1975 prohibited women to have abortions. However, the climate of human rights in the new political dispensation changed all this. In 1996, the Abortion and Sterilisation Act No 2 of 1975 was repealed and the Choice on Termination of Pregnancy Act No 92 of 1996 was promulgated. The Act recognises the rights of women to make decisions concerning reproduction and control over their bodies. It also recognises the right of women to have access to reproductive health care including family planning, contraception and termination of pregnancy. The Act also recognises that the state has the responsibility to provide safe conditions which will enable women to exercise the right of choice without fear or harm. The Act therefore extends to women freedom of choice and it also allows every woman the right to have an early and legal termination of pregnancy if she so wishes (Nolte 1998:265).

The Supreme Court of the United States of America ruled in the case of Roe versus Wade, on January, 22, 1973 that "a state could not interfere in the abortion decision between a woman and her physician during the first trimester" (Davis and Aroskar 1983:120). According to this decision, "Foetuses are not full legal person" and women have a right to privacy (Grassian 1992:247). This decision gave women the right to abortion on demand. The court ruled further that in the second and third trimesters when abortions become risky the state had "a legitimate interest in preserving and protecting the health of the woman" (Grassian 1992:247). The Court gave the woman the decision whether or not to terminate her pregnancy, but did not support the position that a woman had an absolute right to abortion. However, the Court made legal abortion available than before.

Nearly three decades after the Supreme Court ruling in the Roe versus Wade case, abortion continues to be debated vigorously in the USA (Grassian 1992:247-248; Steinbock 1992:43; Davis and Aroskar 1983:120).

\section{Human life : Beginning}

The fundamental philosophical question in determining the morality or immorality of abortion is to ask ourselves whether or not a foetus is a person. To answer this question, we also have to ask ourselves when does human life begin? In an attempt to answer this question Callahan in Thiroux (1990:247) identifies three basic orientation to personhood namely: the genetic viewpoint, the developmental viewpoint and the school of social consequences viewpoint.

1.The genetic viewpoint defines a human person as any being that has a human genetic code. This approach would argue that personhood comes at the beginning of life. That is, from the moment of conception. Furthermore, growth and development are seen as simply endorsing what has been genetically determined.

2.The developmental viewpoint is in agreement with the ge- 
maintains that there must be some degree of development for a being to be considered a full human person.

3. The third viewpoint is the school of social consequences which focuses on what society sees as valuable for personal existence. Society has to determine what kind of persons it desires and then set the definition in accordance with that. This means that the desires of society as expressed in public policy "takes precedence over the biological or developmental aspects" (Shannon 1987:43; Thiroux 1990:247).

The developmental viewpoint is significant in understanding the conceptus. The potential for human life exists in the various stages of development during pregnancy. The conceptus passes through various key stages of development, everyone of which is important. However, the more the conceptus becomes viable the more human qualities it acquires. Baird and Rosenbaum (1989:78) identify the following as the most central traits of personhood in the moral sense:

1. Consciousness (of objects and events external and/or internal to the being) and in particular the capacity to feel pain;

2. Reasoning (the developed capacity to solve problems);

3. Self-motivated activity;

4. The capacity to communicate; and

5. The presence of self-concept and self-awareness either individual or racial or even both.

Given these characteristics, how far advanced in pregnancy does a conceptus acquire a right to life by virtue of being like a person? To what extent does its potentiality for becoming a person endow it with a right to life? In answering these questions, it seems reasonable to state that the more the conceptus resembles a person, the stronger is the case of granting it the right to life. In the religious context the sanctity of life is paramount. It becomes unimportant to state with certainty when a conceptus becomes an person. What is important is that God's love for man transcends all the biological processes. "Before I formed thee in the belly I knew thee; and before thou comest forth out of the womb I sanctified thee; and I ordained thee ..." (Baird and Rosenbaum 1987:67). According to this viewpoint God created man not because it could be proven pre or post natal that at a certain point the conceptus is a person and a bearer of right; rather, that God loved man long before he was formed. "His essence is his existence before God as it is from Him" (Baird and Rosenbaum 1987:67).

Since life is a loan from God, man should therefore, respect his own life and that of his fellow men. However, the sanctity of life argument assumes that man does not make any decisions concerning the span of human life. His destiny is viewed as predetermined. Technological advancement however, has made man/woman to assume more responsibility for his/her decisions including pregnancy.

The sanctity of life viewpoint concurs with the viewpoint of the pro-life group that human life begins at conception and that abortion must be wrong because it is murder. However, in defence of abortion the pro-choice group argues on the premise that killing an innocent person in self-defence is justifiable. If the pregnancy threatens the woman's life, killing of the conceptus may be justifiable.

On the other hand, let us assume that a foetus is not a person, would abortion always be morally permissible? In my view, abortion would not always be permissible even if a foetus was not a person. Animals are not persons but, it is wrong to torture or kill them for no reason whatsoever. Our moral codes dictate that a foetus should be given some consideration though its interests may be overridden by those of the woman.

Any prohibition against killing is based on some moral sentiments which include sympathy, compassion and guilt. These sentiments are also experienced towards non persons. These sentiments are also experienced towards the foetus particularly during the last trimester when the foetus resembles a new born baby. In the last trimester, even in our assumption that a foetus is not a person, abortion seems to be wrong except when the pregnancy threatens the woman's life (Baird and Rosenbaum 1987:89-92).

\section{Pro-life arguments}

The pro life position holds the view that abortion is never morally justifiable because life begins at conception. This position is based on several arguments:

\section{The Genetic Viewpoint}

The pro-life view is that life begins at conception. This group values the conceptus in an equal way as it values a new-born baby. It argues that the person's genetic make up is established at conception and once established, it programmes the creation of a unique individual. They also agree with the religious viewpoint that the zygote is infused with the "soul" at conception and that we have to act morally towards human life, especially innocent human life.

\section{The Sanctity of Life Argument}

The sanctity of life argument states that every unborn baby must be regarded as a human person from the moment of conception. The conceptus is seen as having an absolute right to life. This means that the conceptus' right to life overrides all other rights that might be in conflict with it, such as a woman's right to her own body or even her right to decide between her own life and that of the conceptus, especially if pregnancy has some complications.

\section{The Slippery Slope Argument or Domino Argument}

According to the proponents of pro-life, the slippery slope argument is more forceful when applied to abortion than to any other issue. The reason is that abortion is not as visible as murdering of adults. It is easier for the woman to disregard human life because she does not see her conceptus. 
According to this argument, disregard for any form of human life, born or unborn would lead to the domino effect which would trigger a complete disregard for human life in all its aspects.

\section{The Medical Dangers Argument}

Proponents of the pro-life position argue that abortion procedures are dangerous to the mother's well-being and may lead to infertility. Abortion is also viewed as an intrusion into the woman's vagina and uterus with possible dangerous results.

\section{Psychological Danger Argument}

Proponents of the pro-life position also argue that a woman who has authorised the "killing of her baby" may have to live with a great deal of guilt.

\section{The Relative Safety of Pregnancy}

The relative safety of pregnancy argument is one of the strongest arguments put forward for abortion. The argument is that pregnancy may endanger a woman's health and even her own life. Proponents of pro-life however, argue that the woman's life should be saved without terminating the pregnancy. If the woman's life cannot be saved, she must then sacrifice her own life to allow her child to be born, an action which is not morally acceptable to most people. This view is only acceptable to those who believe that life is God given and not acceptable to atheists. It is, thus, selective.

\section{The Existence of Viable Alternatives to Abortion}

Proponents of the pro-life position argue that abortion is not the only alternative that a mother can take if a child is unwanted or it is born with gross deformities. They argue that childless couples would gladly adopt a child and raise it as their own. There are also many agencies which take care of children who are rejected by their biological parents. The pro-life view also argues that an unwanted or handicapped conceptus cannot be a moral justification for an abortion.

\section{The irrelevance of Economic considerations}

Proponents of the pro-life position argue against the notion that women should seek abortion because they do not have the financial resources to raise the child. Their view is that a woman must accept the financial responsibility for the birth and raising of her child. Families that are financially disadvantaged should use contraceptives to prevent unwanted pregnancies. In no way should financial considerations be used as a reason for an abortion.

\section{Responsibility for Sexual Activities}

The argument for responsibility for sexual activities main- tains that whenever a woman and a man engage in sexual acts, they must realise that pregnancy may occur. They must therefore, accept responsibility for their own actions regardless of whether they use contraceptives or not. However, if the woman does fall pregnant, she must accept the responsibility and go through with it and deliver the baby.

\subsection{Rape and Incest}

Proponents of the pro-life position argue that pregnancies from rape or incest are rare and if rapes are reported in time, contraceptive procedures can be used effectively. The pro-life group does not justify an abortion even when the pregnancy was the result of rape or incest because abortion is seen as the destruction of innocent human life. They maintain that the woman must carry the pregnancy to term and if she does not want the newborn baby because of the circumstances of the conception, she should, place the baby for adoption. This position further argues that innocent, unborn conceptuses should not have to pay with their lives for the sins and crimes of others. (Thiroux 1992:248-253).

\section{Pro-choice arguments}

According to the pro-choice position, a woman ought to be allowed to have an abortion without suffering any guilt or restriction; legal or otherwise. This position is supported as follows:

\section{Absolute Right of Women over their Bodies}

The pro-choice position is of the viewpoint that women should have absolute rights over their bodies, including procreation. Abortion is seen as just another method of birth control that should be available to women should they choose to use it. The pro-choice position also sees the conceptus as part of the woman's body until it is born. As such, she has absolute say over whether it should continue to live in her body until it is born or whether it should be aborted. This group maintains that no woman should be forced to go through a pregnancy against her will. She must be granted the right to decide her own future. The pro-choice position also maintains that women live in a male dominated world which is characterised by strict abortion laws and high morality about the conceptus' life because they do not experience the exhaustion and the pains of labour and delivery.

\section{Birth as the Beginning of Human Life}

The pro-choice position maintains that human life begins after birth; as such the conceptus has no rights until after birth. Most pro-choice women prefer to have abortions performed in the early stages of pregnancy. They also support the performance of abortion should it be discovered later in pregnancy that the foetus has gross abnormalities. This position maintains that the conceptus is not a human person at any stage of development. Therefore, it does not have absolute 
rights to life. Instead, it is the pregnant woman who has absolute rights to her body.

\section{The Problem of Unwanted or Deformed Children}

The availability of contraceptives including abortion ensures that no unwanted children are born. Only children who have been planned for and are wanted should be born. In this way the quality of the lives of children can be ensured. Present conditions such as overpopulation and economic difficulties necessitate that only children who are planned for should be born and abortion makes this possible. This position also maintains that a woman must be given the right to bear a child and raise it but, if she does not want to take responsibility for it, she should be allowed to terminate the pregnancy rather than giving up the child for adoption or have it institutionalised and become a burden to society.

This argument assumes that adoption is a poor solution because if the woman does not want the child, she still has to go through the pregnancy which will interfere with her own freedom and life in general. It is both physically and psychologically traumatic for the woman to go through pregnancy and later give up the baby for adoption when it is born. Abortion is less traumatic. Furthermore, adoptive children feel rejected when they discover that their natural mothers gave them up. Often they search for their natural parents regardless of the love and quality of life of their adoptive parents and homes. Also some of these children end up in foster homes and endure a poor quality of life.

The pro-choice argument also assumes that life in institutions established for orphaned and grossly handicapped children is inhumane and the quality of care available for these children is often poor. Hence giving up a child to these institutions is regarded as worse than terminating the infant before it is born. This position also argues that no woman should be required to give birth or raise a deformed child if she does not want. The availability of the amniocentesis procedure makes it possible for the woman to know whether or not the child will be deformed. She can therefore, choose to give birth or abort the conceptus.

\section{The relative Safety of Abortion}

The pro-choice group disputes the argument presented by the pro-life group that abortion is dangerous to the woman's health and psychological well-being. The pro-choice group maintains that the only dangerous abortions are either self-induced or those performed by unskilled personnel under poor sanitary conditions. The legalisation of abortion has minimised the risks because it is now performed by qualified personnel in designated medical settings. Scientific and medical advancements have also made it possible for abortion to be safer even in the late stages of pregnancy.

Some women who decide to have an abortion may experience a feeling of guilt, but many women who do not consider the conceptus a person do not experience such feelings. How- ever, if these women do experience any guilt feelings, they can be helped to overcome these feelings through counselling. The pro-choice group argues that these guilt feelings are temporary and they cannot be compared to the psychological trauma of going through with the pregnancy and then bearing an unwanted infant. They also argue that children who grow up unwanted and unloved by their mothers tend to be abusers themselves.

\section{Refutation of the Slippery Slope Argument - Domino Argument}

The pro-choice group refutes the domino argument. According to this group there is no evidence that shows that legalisation of abortion will result in loss of reverence for human life. They further argue that they are not interested in compulsory abortion. Rather, what they want is the freedom of choice for women who do not want to keep their pregnancies. Legalising abortion does not mean that every woman will be forced to terminate her pregnancy, but it means that it offers women the freedom to choose abortion or not. They further argue that the availability of abortion has not in any way made women lose reverence for human life. Instead, women become more loving towards the children they really wanted and planned for.

\section{The Dangers of Pregnancy to the Mother's Life}

The pro-choice group argues that pregnancy sometimes poses serious threats to the woman's health and life. This group further argues that the woman's life must take precedence over the life of an unborn conceptus. Women have established social relationships while, the conceptus has no such relationships.

\section{Rape and Incest}

The pro-choice group maintains that rape and incest are the most serious crimes committed against women. Therefore, under no circumstances should a woman who is a victim of rape and incest be forced to keep an unwanted pregnancy resulting from these crimes. She should have a choice of whether she wants to continue with the pregnancy or not.

\section{Responsibility for Sexual Activities}

Proponents of pro-choice are in agreement with the proponent of pro-life that women must accept responsibility for their sexual activities. However, they believe that this responsibility should also include the right to terminate a pregnancy. Most women are disturbed by the notion that they should accept responsibility for their carelessness should they fall pregnant. They feel that no matter how pregnancy results, the woman does not deserve punishment anymore than the man who is also responsible for the pregnancy. She should not be abused or discriminated against for exercising her freedom in dealing with her problem. 


\section{Abortion as the Woman's Choice}

The final argument for the pro-choice position is that women should be legally free to make private decisions about their own bodies and their lives. No one else has to go through: (i) pregnancy, (ii) childbirth and (iii) raising the child, if she does not want to. Therefore the decision to continue or terminate a pregnancy should solely be taken by the woman with no interference from anyone else (Thiroux 1990:253-258).

\section{The moderate position on abortion}

The pro-life and pro-choice positions are extreme views to the abortion issue. The moderate position considers abortion acceptable up to a certain point in foetal development. What follows is a discussion of the basic assumptions that the moderate position holds on the abortion issue.

\section{Conflicting Absolutes}

One realises that the abortion issue is very complex indeed. Two basic principles come into conflict: the value of life principle and the principle of autonomy. There are no absolute rights. The value of life principle is important but it is not the only value that should be considered. There are other important aspects of this principle. For example families should also be given the right to procreate and to reproduce the number of children they want to facilitate the care of their offsprings.

Similarly, there are no absolute rights over one's body. The right of a pregnant woman over her body is important, but people should be prevented from killing indiscriminately. Presently, the pregnant woman's body and her life contains another body and life that is in some stage of development. For this reason, the argument that she should have absolute right over her own body does not hold because, what affects her body and life will also affect the body and life of another potential person. However, this does not mean that the woman forfeits her rights over her body and her life. What it means is that when she makes her decision, she has to consider that her body is carrying a potential or actual human life. Therefore, she does not have absolute rights over her own body. The conceptus too does not have an absolute right to life (Thiroux 1990:259-260).

\section{Recommendations}

Nothing that abortion is an ethical dilemma that confronts health professionals the following recommendations are, therefore, made with the hope that they will go a long way in helping institutions and individual health professionals deal with this issue.

1. Health provision centres should have an employment policy document which outlines the duties and requirements of health professionals pertaining to abortion.

2. Prospective employees should be made aware of these requirements during interviews to afford them the opportunity of making informed decisions to take the post or decline it based on their convictions on the issue.

3. Workshops should be conducted where nurses are briefed on what they may experience with their feelings particularly when they have participated in large numbers of abortions. 4. Las but not least debriefing sessions should also be conducted for health professionals who experience feelings of anxiety, depression and ambivalence as a result of participation in large number of abortion.

\section{Conclusion}

The morality and immorality of abortion was determined by attempting to answer the central philosophical question which relates to moral status of a foetus. At the centre of the pro-life argument is the humanity of the foetus. While, at the centre of the pro-choice argument is the pregnant woman's right to self-determination. The pro-life position argues that the conceptus has absolute rights to life. While, the pro-choice group argues that the woman has the right to make decisions about her body including the conceptus she is carrying. The principle of Autonomy becomes important in this regard. Grassian (1992:259) states that the reasons we give for the different viewpoints on the abortion issue are motivated by our "feelings of identification more than reason." For the pro-life group, these feelings of identification focus on the developing foetus, while, for the pro-choice group they focus on the wishes or suffering of the pregnant woman. For the former, abortion is felt to be immoral, while for the latter it is felt to be moral. It is thus, an issue of value rather than an issue of facts.

It is very difficult to justify any specific time as the point at which a conceptus becomes a person and as such a bearer of moral rights. The pro-life group draws the line as to when the conceptus becomes a person too early. Moderates would find it difficult to accept that a group of cells (regardless of their potentiality) without any form has to be considered as a person. On the other hand, it is also difficult to accept the notion that personhood begins at birth as indicated by the pro-choice group. This view disregard the potentiality towards actual human life that occurs throughout pregnancy.

According to Thiroux (1990:260) Daniel Callahan accepts the developmental viewpoint as the best approach in understanding the conceptus. This view maintains that while it is true that the genetic basis of an individual person is established at conception, some development has to take place before the conceptus can be called human. This viewpoint accepts that human life in potentiality exist in various stages of development throughout pregnancy. It further states that since the biological development of a person occurs in a continuous manner, it might be important to consider the possibility that human rights also develop in the same manner.

What is illustrated is that there is human life either in poten- 
tiality or in actuality from conception. The fact that an entity is a potential person is a strong prima facie reason for not destroying it. However, we need not conclude that a potential person has a right to life by virtue of that potential. At the same time we need not insist that a potential person has no right to life whatsoever. As we make our moral judgement regarding whether abortion is right or wrong, it is important to consider not only that life is lost but it is also important to consider the motive and intention of the person's actions.

\section{References}

BAIRD, R M \& ROSENBAUM S E Ed 1989: The Ethics of Abortion. New York: Prometheus Books.

DAVIS, ANNE J AND AROSKAR, MILLA A 1983: Ethical Dilemmas and Nursing Practice. Connecticut: AppletonCentury-Croft.

GRASSIAN, VICTOR 1992: Moral Reasoning. New Jersey: Englewood Cliffs.

NOLTE ANNA (Ed) 1998: A Textbook for Midwives. Pretoria: JL Van Schaik.

SHANNON, THOMAS A 1987: An Introduction to Bioethics. Second edition. USA: Paulist Press.

SOUTH AFRICA 1996: Choice of Termination of Pregnancy Act (Act 92 of 1996). Pretoria: Government Printer.

STEINBOCK, BONNIE 1992: Life before Birth. New York: Oxford University.

THIROUX, JACQUES P 1990: Ethics Theory and Practice. Fourth edition. New York: Macmillan Publishers. 